\title{
The Disintegration of the American Family in Joyce Carol Oates's Fiction
}

\author{
Entela Kushta \\ University of Tirana \\ Email: entelakushta@yahoo.com
}

\section{Doi:10.5901/ajis.2012.v2n4p155}

\section{Abstract:}

Joyce Carol Oates is undoubtedly one of the contemporary writers in the American literature who writes about the evils of the American society. But what adds originality to her approach is the absence of interpretations or value judgment about what she is reporting. She places herself in the position of an observer who merely states the facts that she sees. Through the employment of contemporary historical events and actual physical places, Oates is both a novelist and a social critic. She chooses this way, though not clearly stated, to show Americans that they are the characters of her novels and pointing out the direction in which their lives are headed. Her early novels, With Shuddering Fall (1964), A Garden of Earthly Delights (1967), Expensive People (1968), them (1969), Wonderland (1971), and Do with Me What You Will (1973) deal with people in various environments, and despite the difference in plot these novels are all united by a common spirit of materialism permeating the American family as a whole. The purpose of this study is to consider the social criticism in the novels by examining in detail the process of disintegration the American family is going through, as it appears in various settings: the rural, the urban and the suburban.

Key words: Family, decadence, rural, urban, suburban

\section{Introduction}

Joyce Carol Oates is among the numerous American writers who have written about the ills of American society. But what makes her distinct is her unique approach aiming not at making overt interpretations or value judgments about what she is reporting. Her reader can infer the garb of a social realist who justifies her concern with familial disintegration in America. Oates believes that "A writer's job, ideally, is to act as the conscience of his race. I wouldn't be honest as a writer if I ignore the actual conditions around me" (Graham, Judith 1978:60)

Her novels witness blood, violence, death, and lust but the presence of these elements is never accompanied by emotional involvement on the part of the author. She manages to keep the necessary aesthetic distance, which allows for the mere stating of facts. Characters are never good or evil, they are merely human. Despite the lack of judgments and moralistic statements, $20^{\text {th }}$ century readers see their lives in her books, and most are depressed by what they see. Love is almost totally lacking, replaced by lust and violence, and "loving is equated with a surrender of identity; the double-bind is such that the moments of heightened love are always moments of murder. . . "(Gordon, Jan B. 1972:450)

If she is truly showing the "social and moral conditions of [her] generation," then she apparently believes in the statements that are being made in her fiction that Gothicism is no longer merely a literary tradition, but it is the realistic picture of the decadence that currently prevails in American families. This fact explains for the presence of a number of fictional devices, among them the gothic trappings, all of which pointing to her major criticism of American society: that the institution of the American family is disintegrating, that in reality it has become one with the fictional gothic family. Oates voices her concern about the disintegration process the American family is undergoing through the words of one of her characters "Family is a vanishing animal in the United States, doomed to extinction." (Oates, Joyce Carol, 1984:22)

In other words Oates attempts to make her compatriots aware that they are the characters of her novels and pointing out the direction in which their lives are headed. She writes about people of all walks of American 
life. Her six novels, With Shuddering Fall (1964), A Garden of Earthly Delights (1967), Expensive People (1968), them (1969), Wonderland (1971), and Do with Me What You Will (1973) deal with people in various environments, and the purpose of this study is to consider the social criticism in these novels by examining in detail the disintegration of the American family as it appears in various settings: the rural, the urban, and the suburban. With Shuddering Fall and A Garden of Earthly Delights, show Americans in rural settings struggling with the problems of family life. For urban dwellers, Oates has written them and Do with Me What You Will, two novels about the decadent family in the city. To be sure to include everyone, Oates has also written about the suburbanites, those former city people who escaped to the suburbs to get away from the problems of the city. These people are found in Expensive People and Wonderland, but these novels, too, show that decadence, in the shape of disintegrating individuals and family units, is everywhere, even in suburbia.

\section{The rural family}

Traditionally American novels set in rural settings associate agrarian life with hard work, but it is usually alleviated through a sense of togetherness and affection between family members. The family is a secure and tightly-structured unit held together with strong bonds of love. This is not the reality of Joyce Carol Oates's novels, where these bonds are obviously absent. The tough economic conditions are not the only ones to be blamed for the disconnected feelings the members of her fictional experience. In fact what they lack is real feelings of love. They each seek separate identities unrelated to the background or unity of their immediate families.

Death forces Karen in With Shuddering Fall to leave her childhood environment. By lacking in natural affection towards other family members, Karen is considered an instance of the modern rural inhabitant. Instead of the usual intimacy, she can only feel indifference for her brothers. Being given a religious training she knows that her strange attitude toward the family unit is errant, and she is torn by what she has been taught and what she is currently experiencing.

Consciously Karen feels bound by the traditional respect for family members, even though subconsciously she is growing away from rural customs. In order to actively seek out life, she had to reject her family and her home, but when urban life also betrayed her, she had to return to the only other existence she knew: that of the rural family. She does accept her family eventually, but though the reunion may seem superficially a happy ending, the reader is dissatisfied because the price to be paid is very high. Karen has to renounce her keen mind for a place in the family.

A home and a stable family, considered to be typically true about rural families, are not present in the early portions of $A$ Garden of Earthly Delights, in which the Walpoles, Carleton and Pearl Walpole, are migrant farm workers without roots or stability. They are forced to become itinerant vegetable pickers when year after year of crop failure leaves them deeply in debt. At first you hear them talking of returning "home" to Kentucky, but after a while they forget what Kentucky was like and eventually quit talking of it altogether. Pearl, the wife in the novel, loses her girlish attractiveness, as several pregnancies leave her shapeless, while hard work and broken dreams slowly destroy her mind.

Pearl's death changes nothing but the focus of the maternal role; she is easily replaced by a younger and stronger woman. Clara Walpole, Pearl's daughter around whom the novel revolves, apparently feels no strong ties to her natural mother, and the death of Pearl is reported only briefly in the course of the action, as though the incident were trivial and insignificant. Clara's ties, in fact, are not to the family or to the land, as might be expected in a novel about rural families; her only concern is for herself. Like Karen Herz, Clara is seeking to break away from her family to starting a new life in the chaotic world of $20^{\text {th }}$ century America.

The fact that both Karen and Clara grow up essentially without mothers is significant in the analysis of the breakup of the family units. Both girls decide to seek different kinds of lives from those of their parents. The ending is what brings their routes apart. While Karen eventually returns to her family, Clara empties her mind from all memories and thoughts of her family when she leaves them. If Karen's return signals a sort of 
resignation on her part, then Clara's determination to make her own way can be viewed as positive steps in the process of maturation.

Clara's crying indicates that she wants more out of life than that which she is now getting, and her subsequent stealing of a flag from the yard of the home serves as a token to remind her of what is available to people who live in towns. The flag, maintained as a symbol of a nation's independence, it may as well symbolize Clara's beginning of an independent life. This freedom has not been granted to her. She has to steal it. Her theft is a turning point in the novel, for at that point she realizes that she can break away from her family and their struggles, and that she can be independent. She keeps the flag as a reminder of what will someday happen.

The novel's ending suits Clara's character. She should spend her last years in a nursing home, away from family of any sort, finally giving her life over to the television and failing even to notice when her husband's son comes to visit her. After fifty years of struggling to obtain a real family, Clara Walpole must admit defeat; she can only fill the void in her life by starring at the unreal figures moving across the screen, which take her away from all her memories.

A Garden of Earthly Delights is not only the story of one woman's fight for a family, but it is also the unveiling of the plight of rural families. No home can escape the degradation and divisiveness that occurs throughout the novel. The more Clara searches and struggles for roots, the more aware she becomes of the desperate familial situation. Eventually, she reaches the conclusion that families exist only in the make-believe world of television where men can die and be reborn each hour.

Oates's rural families are not traditional representatives, but perhaps they exemplify her view of life in rural America today. With growing industrialization and rapidly changing times, people are experiencing new feelings and new problems that the more traditional family cannot understand, and the old ties of love and affection are weakening. The formerly strong structure of the rural family is loosening, and the family unit is dying from neglect.

\section{The urban family}

The urban family is in no better situation in Oates's novels than the rural family. Its members suffer the same incoherent, irrational feelings seen in the characters of Karen and Clara. They only differ in the environment and the reasons they attach to their downfall.

them centers around poor families in the city, families whose lives are determined by their financial situations. The Botsfords of them blame the city and unemployment for a large part of their problems. The Botsford family history is confusing to Loretta, the daughter of the novel, who nevertheless tries somehow to keep track of time and people by remembering who she is and where she came from. She does not question the reasons for their inferior dwelling and their lack of luxuries; she compassionately accepts whatever situations arise, never feeling embittered as Brock, her brother does. Loretta is the only Botsford who understands love, but love is not enough to survive the struggle of the family.

She gets married to Howard Wendall and three children are born out of this marriage, Jules, Maureen and Betty. Despite the strenuous living, Loretta has daydreams of a life before the one they now have in Detroit. However, an industrial accident claims the life of Howard Wendall, and the event serves to further point out the corruption of the city, although the country life that they experienced briefly was no better. His death, however, hardly upsets the Wendall household. Immediately after the funeral, Jules goes for a walk and finds himself unable to remember his father's face or voice, as though the father had been absent from the family for years and his death were merely an outward sign of his removal. This urban family, sick and decaying, can feel no love for the loss of a primary member of the relationship, and this situation, while perhaps shocking, is quite predictable in Oates's novels.

Gradually the emphasis in them shifts from Loretta and Jules to Maureen, the middle child and perhaps the only Wendall with any love left for her family. She tries to bring the family together, but an important event at this point of the novel foreshadows what will happen with her. It is on this day that Maureen loses the 
important secretary's notebook with which she has been entrusted by her teacher and classmates. Actually the loss of the notebook is important as an outward sign of what she really lost that day: her only tie with familial love. The chapter concludes with thematic foreshadowing: "She kept looking, but she never found the notebook" (Oates, Joyce Carol., 1969:159)

The lack of love that is shown by the family is in a small scale the conditions which are characteristic of the urban society as a whole; people care only about themselves, and all others are merely inconvenient objects. As a parallel to the unrest in the Wendall household, the Detroit Riots of 1968 occur at the climax of their struggle, indicating that the selfishness and instability felt by Loretta and her children reflect somehow the feelings of all urban dwellers. Chaos is rampant in the entire city at this time. The final and crushing blow to the Wendall family occurs when Maureen rejects Jules, her brother, the only member of her family for whom she ever felt love. At the conclusion of the novel, the Wendall family is completely destroyed. Loretta has lost track of her children, and Maureen takes the final step toward removing herself from the old family by rejecting her own brother. Though they go on searching for love, Oates's urban dwellers can find none, and their rotten existence becomes lonelier and lonelier.

Though finding themselves in the middle of a big crowd, the individual urbanites are nonetheless lonely and isolated. It is the multitudes of people and the continuous displacement of people which make familiarity impossible and withdrawal a likely defense. In this withdrawal process, then people cannot find the right balance, and thus end up isolating themselves even from those to whom they should feel close. The family unit loses its hold on its members, whereas real familial love is lost in the struggle for individuality.

Elena Ross's parents in Do with Me What You Will experience a divorce which leads to an attempt on the part of each parent to dismiss the life of the other. Elena's mother tells her that her father is dead, but when Elena is kidnapped by her father, he tells her that her mother is dead. In reality, only the relationship between the family members is dead, with both parents fighting for possession of Elena. Neither wants to love her, but both want to own her. The family is destroyed even before the novel begins, and the rest of the book is the story of the individual attempts by Leo, Ardis and Elena to regain a family of some sort. Other families figure in significantly, but they too are decadent; nowhere in the city can a normal familial relationship be seen, according to the picture painted by Oates.

At the age of sixteen Elena, is married unwillingly by her mother to an old man but at least the marriage at least provides Elena with a home and someone who can take care of her. From time to time she continues to think about her mother, who has practically abandoned her since the marriage, but whose words keep reminding Elena of who she is. She starts having an affair with another man. Importantly, the man to whom Elena turns in search of love has also experienced family crumbling. His wife Rachel is an activist in the antiwar movement, and her independence and activity keep their marriage from being totally secure and fulfilling to both members. Elena's passivity is appealing to a man whose wife is anything but passive, and after making love, Jack needing reassurance, asks Elena if she might be able to love him. Elena's response, "I don't know how" (Oates, Joyce Carol., 1973:336) is an honest appraisal of her own emotions and an accurate statement concerning what has happened in the novel to that point.

Despite the novel concluding with Elena and Jack smiling triumphantly at each other, it is nonetheless not an entirely happy ending. Two homes, decadent though they may be, have been broken up, leaving one small child in the process; Elena's father is still at large somewhere, a criminal, hunted by the police; her mother Ardis is in England with a new husband and with a marriage doomed to failure; and Elena and Jack are seeking something in each other that will probably conclude in disappointment for both. The indefinite ending is characteristic of Oates's novels, and in an interview she herself explained why: "You just have to be an extraordinary artist to put in happy endings. I don't know that people need happy books because a happy book is like a happy person - there's nothing to be said about it, nothing to be done to it or for it." (Kuehl, Linda. 1969:310)

The unresolved ending of Do with Me What You Will serves to symbolize families in the urban setting. Like Maureen Wendall in them, Elena recognizes the family for what it has become, and she seeks a different kind of relationship to replace the one with which she has grown up. Maureen thinks that economic stability 
will solve many of her problems, while Elena rejects the comforts of wealth to seek happiness in a relationship with little or no money. The urban dwellers fail to recognize, however, that missing ingredient to a happy family life has nothing to do with the presence or absence of money. What these families lack is unconditional love, and until that element is reintroduced, the new relationships can do nothing to reunite or redefine the existing institution known as the family.

\section{The suburban family}

Joyce Carol Oates does not limit difficulties in family relationships to any particular locale or social class. In her novels, violence, hatred and decadence are evenly distributed among rural families, urban families, and even the newest social innovation, suburban families. Expensive People and Wonderland both contain families that reside in the city suburbs and embody the kind of life Oates presents as typical of that area. Both suburban families are financially comfortable and socially elite, but neither is secure and happy. Though material success has been gained, familial relationships have been lost in the pursuit of the American dream that has led both families to suburbia.

Natashya (Nada) and Elwood Everett of Expensive People are showy, pretentious people, proud of their place in the social hierarchy and struggling hard to live beyond their means. Their cars and their clothes typify their existence; they are obviously moneyed and snobbish. Pretending to be well-off is important to them; in fact, that pretension is the subject of their first argument in the novel.

In the case of Richard, the son of Natashya and Elwood Everett, the lack of parental love makes him feel "as transparent as glass" (Oates, Joyce Carol. 1968:86). When he comes to Fernwood this ten year-old child is "an old man, already," "a doomed, damned child" (Oates, Joyce Carol. 1968:11). Their constant shifting, which is a characteristic feature of modern American life, leaves Richard no scope for establishing close friendship with others. His longing to love and be loved is not even acknowledged. With father mostly on tour, and Nada rarely at home, devoid of close friends, left alone with unconcerned servants Richard, naturally, begins to disintegrate and this turns fatal to Nada.

Though his family is hardly the picture of suburban tranquility, he believes that he and his parents are happy, even though a friend told him once that when the three of them were walking together, they looked like "three strangers who have met by accident on a walk and are waiting for the first chance to get away from one another" (Oates, Joyce Carol. 1968:19) Richard's belief in the family unit is a fantasy that he has constructed to cover the reality of their personalities, though deep inside he knows that its reality is another thing. The child admits to being an eavesdropper, and what he hears is:

"The fight over a stained silk cushion on a Queen Anne chair, on our first day in the house.

The fight over Father's Negro jokes at a party.

The fight over Father's "baggy trousers."

The fight over Father's shirts, which were all dirty.

The fight over Nada's correction of Father's pronunciation of "incognito."

The fight over Nada's naive admiration for the local and internationally famous $\mathrm{H}_{\ldots} \mathrm{F}$ F__ whom Father renounced with middle-class gusto, along with his wife.

The fight following from this, when Father called Nada a parvenu.

The shrieking fight over the mildew in the front lawn, which was gray-blue and deadly.

The hysterical fight over my eye glasses. ("Whose eyes did he inherit whose? He'll have glasses like the bottoms of Coke bottles....")

The fight over the canned goods in the basement store room, whose labels had all peeled off mysteriously.

The fight over the warped piano key-l believe it was $G$ two octaves above middle $C$.

The fight over...

And, a week ago, another fight over-I believe it was over Jean-Paul Sartre, whom Father rejected as a "Communist writer."

And...

And all the other fights that were about nothing." (Oates, Joyce Carol. 1968:82/83) 
The fights continue until no holds are barred and they scream accusations at each other, Nada accusing Elwood of hating her, and Elwood telling Nada that she is neurotic and crazy. Richard's own sad but accurate comment on their emotions explains precisely the state of the suburban family: "When all their stage props were ripped away, they always showed that they needed no fresh reasons to hate. They simply hated" (Oates, Joyce Carol. 1968:84)

The turning point in the Everett family history comes shortly after Richard is expelled from the exclusive boy's school which he has been attending. Richard's own comment, "My heart began to pound as if it knew something already that I myself did not know" (Oates, Joyce Carol. 1968:117), suggests a foreshadowing of events that will eventually result in the total and irrevocable destruction of the family nucleus.

Natashya, the stereotypic suburban mother, according to Oates, is one who is "always backing out of the driveway."Natashya's, the beautiful and highly insensitive mother, only concern is to be part of the affluent but pretentious and selfish suburban culture. In this "whitewashed society with a brainwashed morality" (Grant, Mary Kathryn. 1978:48) this minor writer remains unconcerned about the emotional needs of her husband and son. She is running away from the family responsibilities, and she is leaving behind children who nonetheless worship her. Throughout the novel she remains a self-serving and self-centered mother. Any attempt by Richard to develop a normal mother-son relationship with Nada results in his being rebuffed by her. Only in moments of extreme boredom does she even attempt to communicate with him, but she wants to establish a relationship on her basis, not on his. Her type of relationship calls for Richard to be available when she wants company but to mysteriously vanish when she is tired of him. Natashya desecrates her maternal role when she insists Richard that she be called only "Nada" and not "Mother". In a weak moment, she comes to him and tries to interest him in going out for something to eat, and Richard inadvertently calls her "Mother." Nada's dignity is insulted, and her heated response vividly outlines her feelings toward motherhood.

"What's this, now you're calling me Mother? Weaned at last? Don't give me that solemn weepy look through your glasses, my friend; I don't particularly care to be called Mother by anyone. I don't respond to it. I'm trying to hold my own and that's it. No Mother, no Son. No depending on anyone else. I want you to be so free, Richard that you stink of it. You're not going to blame me for anything." (Oates, Joyce Carol., 1968:188)

The scene signifies an important step toward Richard's murdering his mother; he is shut out from all involvement with her and is treated as though he does not exist, as in reality he was almost aborted before birth and his life since then has been as a sort of unwanted non-entity. With a little planning so as to elude police, Richard shoots and kills his mother. His former feelings of power and strength derived from pulling the trigger do not occur this time; there will be no reward for this killing. Nada is dead of necessity; Richard could no longer stand having a mother who rejects him.

Expensive People, then, traces the Everetts through their lives as a suburban family and shows the decline of familial relationships in that setting. The mother is primarily to blame for the family's failures, who belongs to "the unrelenting gallery of hostile mother s populating Oates's fiction"(Mikelson, Anne. Z. 1979:27). But Oates also provides background clues to show that she too is a product of her family environment. Living in an expensive house and entertaining wealthy people does not give the Everetts the satisfaction they are seeking. Nada escapes from her urban parents and their restraints. The constricting relationship that binds children to their parents was not one that she would allow in her life; independence was more attractive than anything the suburb or the city had to offer. She flees from her family only to find out that suburban life also has responsibilities, responsibilities that she does not want and cannot handle. The decadent family in this novel is the result of the lack of love that necessarily occurs between selfish people, but it is the child of the family who suffers the most even though he is the one who has the capacity for loving. As has been the case with urban families and rural families, the mother holds in her hands the ability to create whatever family atmosphere she desires, but contemporary mothers, at least in Oates's novels, refuse to look beyond themselves.

Wonderland is mainly the story of Jesse Harte Pedersen Vogel, who in later years becomes a prominent physician with a large suburban home and two teenage daughters. Significantly, the Vogels at the beginning of the novel were not a suburban family. They were the embodiment of the American dream of 
success: Jesse was trying to succeed in his medical studies so that he could secure a comfortable financial situation for his family, and by doing so could climb up the social ladder. The city was the place which ensured Jesse that all of his dreams could become true. Though Helene, his wife gave Jesse children, with them he began to grow away from his family. Helene, on the other hand doesn't seem to be bothered by the distance dividing her from her husband. She is fighting for her individuality. Thus, their marriage is a mere wrapping of something inexistent. The family has totally crumbled. Not even the original two members can feel any closeness between them, let alone the children who feel displaced as members of that family. It's no wonder that the last portion of the book is devoted to his daughter Shelley's escape from her suburban home.

Shelley is well aware of the fact that Helene as a mother lacks the natural affection which characterizes mothers. She considers her to be a materialistic suburban woman, who is more concerned about teaching her daughter's good manners rather than nurturing her inner person. Consequently Shelley runs away with a young man to seek a different kind of life, one which has no resemblance with her trivial existence in the suburbs of the city. She is desperately in search of that kind of stable relationships that exist in "typical" American families. In the letters she addresses to her father her desire to reach out for a parent and a home can easily be noticed. However, her escape is a rebelling against that kind of family the Vogels have become. Yet subconsciously she still longs for a return home. She allows her sub consciousness to be heard while she writes to her father: "Father, I want to come home" (Oates, Joyce Carol 1971:381).

Shelley's relationship with her father is controversial in nature. It's a love and hate bondage within the two. Her father is for her a constant reminder of death. He is dealing with death every day of his life. She also hates him for the lack of openness. He has never let her know him as he really is. The only things she knows about him come from sources other than him, like newspaper articles and patients' recounting. Yet she cannot totally deny him since he is the only real parent she has. While she is away from home, her mother Helene does not seem to be worried about her daughter's situation. She will make no effort to search for Shelley. She tells her husband: "Better to think of her as dead" (Oates, Joyce Carol 1971:463)

In search for a substitute to her family and home, Shelley will eventually find only more death. She turns to drugs to stripe her mind off what recalls her of her father. She even refuses to go on the street because all the men she sees, reminds her of her father. Finally her father is able to find her and in his strong arms she becomes passive and child-like. Jesse nevertheless believes that Shelley's place is her parents' house, even though the girl he once knew is dead and the home to which he is taking her is dying and inhabited by dead people. Shelley's dazed statement, "You are the devil . . ."is answered back by Jesse's question, "Am I?"(Oates, Joyce Carol. 1971:479) which marks the ending of the book. Though being physically near each other, this suburban family has finally destroyed itself completely. Its members can only suffer in the flames of this family hell.

Though no literal deaths will separate the Vogel family, the familial bonds are nonetheless as weakened as they are in the Everett household. Even Natashya can be said to have died before Richard literally killed her. For many years she was dead, though being physically alive. Shelley's transformation into another person does nothing in changing the family situation. A strange person is now entering the Vogel's house, but she didn't feel at home even before running away from her family. Shelley at least had the courage to recognize the decadent state of her family and seek to escape, but she couldn't find a better family. It was only different from hers. The bringing home of the daughter does not signify a happy ending; the family will not be united by her return and the Vogel hell will continue for its family members.

\section{Conclusion}

Throughout the six novels, characters continue to be dissatisfied with family life and its conditions in that period of American history the novels witness. However none is able to go beyond his past and find a new stability for his family. Over and over, materialism seems to get in the way of love, and the result is selfishness and insecure, loveless relationships. Land does not provide rural families with serenity or innocence. Their family units are weakly structured and the members are leaving the country to seek out new relationships 
away from the home. The city offers no relief from the emptiness of the family; urban families too are dying and losing their members to the search for stability. A not only family in the novels, but the entire city is infected with the disease of selfishness. Even the suburbia is no longer the haven from the apathy that has infected families elsewhere, for decadence has invaded there, too.

The six Oates novels appeared between the years of 1964 and 1973, and little change is seen in the fictional families during the nine years that they cover. The Howes of Do With Me What You Will (1973) are equally as lost and selfish as the Herzesof With Shuddering Fall (1964). Elena Howe's search marks a change in the pattern of women returning home, after their quest for something better has resulted in destruction. A fact worth noting is that she recognizes the need for love in a familial relationship and attempts to create a family based on love instead of money. The relationship is not ideal, but it at least is somewhat more hopeful than the one she had before the end of the novel and it leaves readers optimistic about the future fate of the American family.

However, the trilogy written by Oates in the 1990s once again depicts victimized women, which suggests that perhaps she is returning to the tragic vision of the 1960s. The novels of this period mirror current realities, especially the widening gap between the rich and the poor, as well as the discrimination against African Americans and immigrants. Brenda Daly in her book Lavish Self-Divisions (1996) tries to provide the reasons which can count for her return to the tragic. "Oates's emphasis on victimization ... . suggests that she sees this as a dangerous era, a time when Americans must once again face the hard problems that will determine our collective identity and destiny." (Daly, Brenda.1996:226).

Significantly, Oates has answered this crisis of the American society not by retreating from it but by intensifying it further more. She stills confirms her conviction that this is exactly a writer's job. As she told David Germain in 1988, "I'm more or less of the school of the writer as witness, witness to history and society." (Germain, David.1989:173). In essence what hasn't experienced any changes over these decades of a long writing career, is her mission as a writer. She persists in asking her readers to examine the roots of evils in our society. Unless it is started from inside the family, society as a whole is bound to failure.

\section{References:}

Daly, Brenda. 1996. Lavish Self-Divisions: The Novels of Joyce Carol Oates, Jackson: University Press of Mississippi. P. 226

Graham, Judith, ed., 1994, Current Biography Yearbook, and 55th Annual Accumulation (New York: H. W. Wilson. Grant, Mary Kathryn. 1978. The Tragic Vision of Joyce Carol Oates. Durham, NC: Duke University Press. P.48 Germain. David. 1989 "Author Oates Tells Where She's Been, Where She's Going." Conversations with Joyce Carol Oates. Jackson: University Press of Mississippi, pp.173-80

Gordon, Jan B. 1972. "Gothic Fiction and the Losing Battle to Contain Oneself," Commonwealth, 95 (11), P.450

Kuehl, Linda. 1969. An Interview with Joyce Carol Oates, Commonwealth, 91.P.310.

Mikelson, Anne Z. 1979 Sexual love in the Fiction of Joyce Carol Oates. Reaching Out: Sensitivity and Order in Recent American Fiction. Metuchen. NJ: Scarecrow, p.15-34.

Oates, Joyce Carol .1984. Last Days. New York: Dutton. p.22

Oates, Joyce Carol. 1973. Do with Me What You Will Greenwich, Connecticut: Fawcett Publications, Inc., p. 336

Oates, Joyce Carol. 1971. Wonderland Greenwich, Connecticut: Fawcett Publications, Inc, p.381, 463, 479.

Oates, Joyce Carol. 1969. them Greenwich, Connecticut: Fawcett Publications, Inc., p. 159.

Oates, Joyce Carol. 1968 Expensive People Greenwich, Connecticut: Fawcett Publications, Inc., p. 82, 83, 84, 86, 117, 188 